\title{
Hubungan Pajanan Pestisida dengan Kejadian Goiter pada Anak Usia Sekolah Dasar di Area Pertanian Hortikultura Kecamatan Ngablak Kabupaten Magelang
}

\author{
Andriana Marwanto', Onny Setiani' ${ }^{2}$, Suhartono \\ ${ }^{1}$ PoltekkesKemenkes Bengkulu \\ ${ }^{2}$ Fakultas Kesehatan Masyarakat Universitas Diponegoro
}

Info Artikel : Diterima Oktober 2017 ; Disetujui Agustus 2018 ; Publikasi Oktober 2018

\begin{abstract}
ABSTRAK
Latar belakang:Intensitas penggunaan pestisida yang berlebihan dan pelaksanaan penyemprotan yang tidak sesuai aturan dapat mengakibatkan masalah kesehatan bagi anak-anak, yang secara langsung maupun tidak langsung terpajan oleh pestisida. Pestisida dapat mengganggu proses sintesis dan metabolisme hormon tiroid dengan mengganggu reseptor TSH (TSH-r) di kelenjar tiroid. Kelenjar tersebut membesar sebagai kompensasi untuk meningkatkan output hormon tiroid. Pembengkakan leher akibat pembesaran kelenjar tiroiddisebutgoiter. Kelainan kelenjar tiroid pada anak-anak dapat mengakibatkan gangguan tumbuh kembang. Penelitian ini bertujuan untuk mengetahui hubungan riwayat pajanan pestisida dengan kejadian goiter pada siswa-siswa SD di wilayah pertanian hortikultura wilayah kerja Puskesmas Ngablak Kecamatan Ngablak Kabupaten Magelang.

Metode:Penelitian ini menggunakan desain Case control (kasus control). Sampel pada penelitian ini adalah 60 siswa kelas 4-6 yang terdiri dari 20 siswa yang mengalami goiter sebagai kasus dan 40 siswa sebagai kontrol. Data diperoleh dari hasil pemeriksaan kadar UEI dalam urine dan wawancara.

Hasil:sebanyak 60 \% respondenpada kelompok kasus mempunyai riwayat pajanan pestisida dan kadar Ekskresi Iodium Urin (EIU)pada anak mempunyai nilai rata rata (Mean) 176,183 $\mu \mathrm{g} / \mathrm{L}$ dengan kisaran $30 \mu \mathrm{g} / \mathrm{L}$ $291 \mu \mathrm{g} / \mathrm{L}$, nilai median $182 \mu \mathrm{g} / \mathrm{L}$. Riwayat pajanan pestisida secara signifikan berhubungan dengan kejadian goiter dengannilai $p$-value: 0,013 ( $\mathrm{p}<0,05)$, OR; 5,41 95\% CI; 1,53-19,12

Simpulan:Kesimpulan penelitian ini adalah riwayat pajanan pestisida dalam hal keterlibatan anak pada kegiatan pertanian merupakan faktor resiko terhadap kejadian goiter.
\end{abstract}

Kata kunci: Pajanan pestisida; siswa SD; goiter; area pertanian

\footnotetext{
ABSTRACT

Title: Exposure Pesticide Associated with Incidence of Goiter in Elementary School Students in the Areas of Agriculture in Sub District Ngablak District Magelang

Background:The intensity and excessive use of pesticides and spraying methods which not appropriate may cause health problems to farmers exposed directly as well as children who are indirectly exposed to pesticide. Pesticides can disrupt the synthesis process and thyroid hormone metabolism by disturbing the TSH receptor (TSH-r) in thyroid gland. The gland is enlarged as a compensation to increase thyroid hormone output. swelling of the neck from an enlarged thyroid gland is called Goiter. Thyroid unloyment caused by inhibition of thyroid hormone synthesis may cause growth disorders. The purpose of this study was to determine the exposure pesticide associated to the incidence of Goiter in elementary school students in agriculture areas at the Sub District NgablakMagelang. Method:This study was observational study with case control design. The sample in this study were 60 students of grade 4-6 consisting of 20 students who incidence goiter as the case and 40 students as control. The data Data was taken from UEI examination results in urine and interview.

Result:That $60 \%$ of respondents in the case group had a history of pesticide exposure and iodine excretion level of Urine (EIU) in children had mean of 176,183 $\mu \mathrm{g} / \mathrm{L}$ with a range of $30 \mu \mathrm{g} / \mathrm{L}-291 \mu \mathrm{g} / \mathrm{L}$, median value 182 $\mu \mathrm{g} / \mathrm{L}$. The history of pesticide exposure was significantly related to goiter events with p-value values: 0.013 (p $<0.05)$, OR; $5.4195 \%$ CI; 1.53-19.12.
} 
Conclusion:This study concluded thathistory of pesticide exposure in terms of children's involvement in agricultural activities is a risk factor to $g$ incidence of Goiter.

Key words: exposure pesticide; goiter; students; agriculture areas.

\section{PENDAHULUAN}

Gangguan Akibat Kekurangan Yodium (GAKI) merupakan Salah satu masalah kesehatan masyarakat yang dapat menghambat peningkatan mutu sumber daya manusia.Yodium merupakan mikronutrien penting untuk pembentukan hormon tiroid. Hormon tiroid sangat penting untuk metabolisme energi, nutrien dan ion organik, termogenesis serta merangsang pertumbuhan dan perkembangan berbagai jaringan pada periode kritis, juga untuk perkembangan susunan syaraf pusat dan tulang. ${ }^{1}$ Keadaan yang terjadi sebagai akibat dari aktivitas subnormal dari kelenjar tiroid disebut sebagai hipotiroidisme. Kelenjar tersebut membesar sebagai kompensasi untuk meningkatkan output hormon tiroid. pembengkakan leher akibat pembesaran kelenjar tiroiddisebut Goiter (Goitre). ${ }^{2}$ Meningkatnya insidens dan prevalensi anak dengan attention deficit hyperactivity disorder (ADHD) atau autisme dua dekade terakhir, kemungkinan juga disebabkan oleh meningkatnya kasus hipotiroidisme ringan pada ibu hamil yang salah satunya diduga akibat pajanan bahan toksik di lingkungan. ${ }^{3}$ Sementara, bila terjadi pada anak, hipotiroidisme yang terjadi pada anak dapat mengakibatkan gangguan tumbuh kembang, seperti ukuran tubuh yang tidak sesuai umur (cebol) dan Intelligence Quotient (IQ) yang rendah (gangguan kecerdasan) bahkan sampai retardasi mental.

Berdasarkan data WHO Tahun 2010, tercatat ada 130 negara di dunia mengalami masalah GAKI, sebanyak 48\% tinggal di Afrika dan $41 \%$ di Asia Tenggara dan sisanya di Eropa dan Pasifik barat. ${ }^{4}$ Berdasarkan jumlah kabupaten di Indonesia, persentase kabupaten dengan kategori endemis GAKI ringan sebesar 40,2\%; endemis sedang 13,5\%; dan $5,1 \%$ endemis berat.Hasil survei pemetaan GAKI 1996/1998 menunjukkan bahwa, secara nasional, Total Goiter Rate (TGR) pada anak sekolah adalah 9,8\%. Hasil Survei Evaluasi GAKI 2003 menunjukkan bahwa TGR anak sekolah adalah 11,2\% dan nilai median EIU (Ekskresi Iodium Urin) anak sekolah adalah $229 \mu \mathrm{g} / \mathrm{L} .{ }^{5}$ Berdasarkan hasil survey pemetaan GAKI Dinas Kesehatan Kabupaten Magelang tahun 2015 menunjukkan bahwa prevalensi TGR (Total Goiter Rate) pada anak sekolah dasar di kabupaten Magelang sebesar $14 \%$. WHO (World HealthOrganization) menetapkan suatu wilayah sebagai endemis berat bila TGR $\geq 30 \%{ }^{4}$

Pestisida dapat mengganggu proses sintesis dan metabolisme hormon tiroid melalui beberapa mekanisme, yaitu pertama, mengganggu reseptor TSH (TSH-r) di kelenjar tiroid, sehingga TSH yang akan memacu sintesis hormon tiroid tidak dapat masuk ke dalam kelenjar, dan berdampak pada terhambatnya sintesis hormon tiroid;kedua, pestisida menghambat kerja enzim deyodinase tipe satu (D1), yang berfungsi mengkatalis perubahan T4 menjadi T3 (bentuk aktif hormon dalam tubuh); ketiga, karena kemiripan struktur kimia dari pestisida dengan hormon tiroid, hal ini menyebabkan terjadinya persaingan dalam pengikatan oleh reseptor hormon tiroid (TH-r) di sel target dan keempat, pestisida diduga memacu kerja dari enzim D3, yang berfungsi merubah T4 menjadi rT3 (bentuk inaktif hormon tiroid), sehingga tubuh kekurangan bentuk aktif hormon tiroid (T3). ${ }^{6}$

Berdasarkan beberapa penelitian yang sudah dilakukan, tampak bahwa ada potensi bahaya kesehatan akibat pajanan pestisida dosis rendah dalam waktu panjang, khususnya pada masyarakat yang bertempat-tinggal di kawasan pertanian. Wanita Usia Subur WUS atau anak-anak yang tinggal di kawasan pertanian, mungkin tidak secara langsung terlibat dalam kegiatan pertanian yang berisiko kontak dengan pestisida, seperti menyampur dan menyemprotkan pestisida. Namun, kontak melalui residu yang ada di lingkungan, seperti hasil panen, air maupun tanah menempatkan mereka sebagai populasi yang berisiko mengalami berbagai gangguan kesehatan akibat pajanan pestisida. Penelitian tahun 2011 di tiga Sekolah Dasar (SD) di tiga desa pertanian Kabupaten Brebes menyimpulkan, bahwa anak/siswa dengan riwayat pajanan pestisida mempunyai risiko 6,8 kali untuk menderita gondok dibanding anak tanpa riwayat pajanan pestisida ${ }^{7}$

Beberapa penelitian di Kecamatan Ngablak Kabupaten Magelang menunjukkan bahwa terdapat paparan pestisida yang berpengaruh terhadap kesehatan manusia. Beberapa penelitian di Kecamatan Ngablak menunjukkan bahwa terdapat paparan pestisida yang berpengaruh terhadap kesehatan manusia. Penelitian yang dilakukan oleh Sungkawa tahun 2008 pada petani hortikultura disimpulkan bahwa faktor risiko masa kerja petani, lama kerja per hari, jenis pestisida, frekuensi penyemprotan, posisi terhadap arah angin, dan penggunaan alat pelindung diri berpengaruh terhadap kejadian goiter dengan probabilitas sebesar 33,78\%. ${ }^{8}$ Hasil penelitian Kristinatalia tahun 2013 pada petani di Kecamatan Ngablak menunjukkan bahwa sebanyak 48,57 \% petani telah terpapar pestisida arsen dengan kadar arsen dalam urin sebesar $\geq 11,2 \mu \mathrm{g} / \mathrm{l}^{9}$

Salah satu kelompok populasi yang rentan terpapar pestisida yaitu anak-anak yang tinggal di daerah pertanian. Hal ini terkait dalam keterlibatan mereka dalam kegiatan pertanian. Kegiatan tersebut 
meliputi membantu orang tua yang bekerja sebagai petani dan membantu saat musim panen. Pekerjaan orang tua diasumsikan akan berdampak terhadap keterlibatan anak dalam kegiatan pertanian baik secara langsung di area pertanian maupun di rumah. Pada anak usia SD, paparanpestisida dapat terjadi secara langsung yakni karena keterlibatan mereka dalam kegiatan pertanian, atau secara tidak langsung yakni melalui kontak dengan lingkungan, baik air, tanah, maupun makanan yang terkontaminasi oleh residu pestisida.Hasil penelitian Suhartono (2013) yang dilakukan pada anak sekolah dasar di Desa Dukuhlo Kecamatan Bulakamba Kabupaten Brebesmenunjukan 16 dari 28 anak $(57,1 \%)$ positif terdeteksi metabolit pestisida dalam urin. ${ }^{10}$

Berdasarkan fakta yang telah diuraikan di atas, penelitian ini bertujuan untuk mengetahui pengaruh riwayat pajanan pestisida terhadap kejadian goiter pada anak usia sekolah dasar di wilayah pertanian hortikultura Kecamatan Ngablak Kabupaten Magelang.

\section{MATERI DAN METODE}

Penelitian ini merupakan penelitian observasional analitik dengan rancangan Case control (kasus control). untuk menentukan kasus dan kontrol dilakukan skrining pemeriksaan goiter dengan metode palpasi. Hasil palpasi pada subyek dengan grade 1 dan 2 dijadikan kasus, sedangkan grade 0 sebagai kontrol. Populasi studi dalam penelitian ini adalah siswa-siswa SD kelas 4 -6 di SD Kecamatan Ngablak sebanyak 401 siswa. Sampel pada penelitian ini sejumlah 60 siswa yang terdiri dari 20 sampel kasus dan 40 sampel kontrol, pemilihan sampel kontrol di match dengan kasus dalam beberapa kriteria yaitu: umur, jenis kelamin, kelas dan riwayat kejadian goiter pada keluarga. Variabel yang diteliti adalah riwayat pajanan pestisida (Keterlibatan dalam pertanian, kebiasaan bermain di area pertanian, kebiasaan cuci tangan, dan pengelolaan pestisida dalam rumah), riwayat pajanan asap rokok, riwayat pajananobat nyamuk, paparan senyawa kimia dalam plastik, status gizi, asupan iodium dan kejadian goiter. Cara mengumpulkan data melalui wawancara dengan menggunakan kuisioner tertutup, observasi secara langsung, pengukuran tinggi badan, berat badan dan dilakukan pemeriksaan spesimen urin untuk mengetahui kadar iodium urin (EIU) di laboratorium GAKI UNDIP. Analisis data yang digunakan adalah uji chi-square dan Analisis Regresi Logistik

\section{HASIL DAN PEMBAHASAN}

Penelitian ini dilakukan di SD wilayah Kecamatan Ngablak. Kecamatan Ngablakberada di sebelah utara ibu kota Kabupaten Magelang.Kecamatan Ngablak merupakan dataran tinggi, terletak pada ketinggian 1.293 meter di atas permukaan laut, dan berada di lereng Gunung Merbabu.Kecamatan Ngablak terdiri atas 16 Desa yaituDesa Magersari, Bandungrejo, Tejosari, Genikan, Jogonayan, Ngablak, Sumberejo, Madyogondo, Kanigoro, Selomirah, Girirejo, Pandean, Jogoyasan, Pagergunung, Keditan, Seloprojo. Sebagian besar wilayahnya adalah lahan pertanian hortikultura yang meliputi; kol, kentang, wortel, tomat, cabe, dan sebagainya.

Tabel 1. Karakteristik Siswa/Siswi SD di Kecamatan NgablakMagelang tahun 2017

\begin{tabular}{|c|c|c|c|c|}
\hline No & Karakteristik & Kasus $(n=20$ & Kontrol $(n=40)$ & $p$ \\
\hline \multirow[t]{3}{*}{1.} & Jenis Kelamin & & & \\
\hline & Laki-laki & $8(40 \%)$ & $16(40 \%)$ & 1,000 \\
\hline & Perempuan & $12(60 \%)$ & $24(60 \%)$ & \\
\hline \multirow[t]{4}{*}{2.} & Kelas & & & \\
\hline & 4 & $5(25 \%)$ & $10(25 \%)$ & 1,000 \\
\hline & 5 & $8(40 \%)$ & $16(40 \%)$ & \\
\hline & 6 & $7(35 \%)$ & $14(35 \%)$ & \\
\hline \multirow[t]{5}{*}{3.} & Pekerjaan Ayah & & & \\
\hline & PNS & $0(0 \%)$ & $2(5,0 \%)$ & 0,758 \\
\hline & Swasta & $3(15 \%)$ & $6(15,0 \%)$ & \\
\hline & Pedagang/Wiraswasta & $2(10 \%)$ & $5(12,5 \%)$ & \\
\hline & Petani & $15(75 \%)$ & $27(67,5 \%)$ & \\
\hline
\end{tabular}

Hasil penelitian diperoleh distribusi karakteristik Siswa/i berdasarkan jenis kelamin, umur dan kelas pada kelompok kasus dan kontrol berdistribusisama. Usia rata-rata siswa pada kelompok kasus dan kontrol relatif sama, yaitu 10,5 tahun pada kelompok kasus, sedangkan pada kelompok kontrol adalah 10,8 tahun hal ini karena telah dilakukan maching. Kedua variabel tersebut tidak memiliki hubungan dengan kejadian goiter dengan nilai p masing - masing 1,000
Pekerjaan orang tua pada kelompok kasus PNS $0 \%$, swasta $15 \%$, pedagang/wiraswasta $10 \%$, petani $75 \%$, dan pada kelompok kontrol PNS $5 \%$, swasta $15 \%$, pedagang/wiraswasta $12,5 \%$, petani $67,5 \%$. Hal tersebut berarti bahwa pekerjaan orang tua paling banyak pada kelompok kasus dan kontrol adalah petani dan variabel ini tidak berhubungan dengan kejadian goiter pada siswa/i SD dengan nilai $\mathrm{p}=0,758$ 
Tabel 2. Sumber pajanan pestisida yang dapat mempengaruhi kejadian goiter pada Siswa/Siswi SD di Kecamatan NgablakMagelang tahun 2017

\begin{tabular}{|c|c|c|c|c|c|c|}
\hline \multirow{2}{*}{$\begin{array}{l}\text { No } \\
1 .\end{array}$} & Sumber Pajanan Pestisida & Kasus $(\mathrm{n}=20$ & Kontrol $(n=40)$ & $p$ & $O R$ & $95 \% C I$ \\
\hline & $\begin{array}{l}\text { Keterlibatan anak dalam } \\
\text { kegiatan pertanian } \\
\text { Ya } \\
\text { Tidak }\end{array}$ & $\begin{array}{c}15(75 \%) \\
5(25 \%)\end{array}$ & $\begin{array}{l}15(37,5 \%) \\
25(62,5 \%)\end{array}$ & 0,014 & 5,000 & $1,510-16,560$ \\
\hline 2. & $\begin{array}{l}\text { Kebiasaan anak bermain di } \\
\text { area pertanian } \\
\text { Ya } \\
\text { Tidak }\end{array}$ & $\begin{array}{c}16(80 \%) \\
4(20 \%)\end{array}$ & $\begin{array}{l}17(42,5 \%) \\
23(57,5 \%)\end{array}$ & 0,013 & 5,412 & $1,532-19,123$ \\
\hline 3. & $\begin{array}{l}\text { Kebiasaan mencuci tangan } \\
\text { Tidak } \\
\text { Ya }\end{array}$ & $\begin{array}{c}9(45 \%) \\
11(55 \%)\end{array}$ & $\begin{array}{l}15(37,5 \%) \\
25(62,5 \%)\end{array}$ & 0,780 & 1,364 & $0,450-4,050$ \\
\hline 4. & $\begin{array}{l}\text { Pengelolaan pestisida di } \\
\text { dalam rumah } \\
\text { Tidak baik } \\
\text { Baik }\end{array}$ & $\begin{array}{c}12(60 \%) \\
8(40 \%)\end{array}$ & $\begin{array}{l}11(27,5 \%) \\
29(72,5 \%)\end{array}$ & 0,031 & 3,950 & $1,270-12,260$ \\
\hline
\end{tabular}

Pajanan pestisida pada anak yang mengalami goiter berasal dari; $75 \%$ responden ikut terlibat dalam kegiatan pertanian, $80 \%$ responden mempunyai kebiasaan bermain di area pertanian, $45 \%$ responden tidak mempunyai kebiasaan mencuci tangan dan sebanyak $60 \%$ responden terpapar dari pengelolaan pestisida di dalam rumah yang kurang baik. Sumber pajanan pestisida yang berhubungan dengan kejadian goiter adalah keterlibatan anak dalam kegiatan pertanian, kebiasaan bermain di area pertanian dan pengelolaan pestisida dalam rumah dengan nilai $\mathrm{p}$ masing-masing 0,$014 ; 0,013 ; 0,031$.

Tabel 3. Faktor yang berhubungan dengan kejadian goiter pada Siswa/Siswi SD di Kecamatan Ngablak Magelang tahun 2017

\begin{tabular}{|c|c|c|c|c|c|c|}
\hline No & Variabel penelitian & Kasus $(n=20$ & Kontrol $(n=40)$ & $p$ & $O R$ & $95 \% C I$ \\
\hline \multirow[t]{3}{*}{1.} & Riwayat pajanan pestisida & & & & & \\
\hline & Ya & $16(80 \%)$ & $17(42,5 \%)$ & 0,013 & 5,412 & $1,532-19,123$ \\
\hline & Tidak & $4(20 \%)$ & $23(57,5 \%)$ & & & \\
\hline \multirow[t]{3}{*}{2.} & Riwayat pajanan asap rokok & & & & & \\
\hline & Ya & $16(80 \%)$ & $29(72,5 \%)$ & 0,752 & 1,517 & $0,415-5,550$ \\
\hline & Tidak & $4(20 \%)$ & $11(27,5 \%)$ & & & \\
\hline \multirow[t]{3}{*}{3.} & Riwayat pajanan obat nyamuk & & & & & \\
\hline & Ya & $9(45 \%)$ & $17(42,5 \%)$ & 1,000 & 1,107 & $0,375-3,264$ \\
\hline & Tidak & $11(55 \%)$ & $23(57,5 \%)$ & & & \\
\hline \multirow[t]{3}{*}{4.} & $\begin{array}{l}\text { Riwayat penggunaan plastik } \\
\text { pembungkus makanan panas }\end{array}$ & & & & & \\
\hline & $\mathrm{Ya}$ & $12(60 \%)$ & $21(52,5 \%)$ & 0,783 & 1,357 & $0,457-4,032$ \\
\hline & Tidak & $8(40 \%)$ & $19(47,5 \%)$ & & & \\
\hline \multirow[t]{3}{*}{5.} & Status gizi & & & & & \\
\hline & Kurus & $6(30 \%)$ & $6(15 \%)$ & 0,304 & 2,429 & $0,668-8,835$ \\
\hline & Normal & $14(70 \%)$ & $34(85 \%)$ & & & \\
\hline \multirow[t]{4}{*}{6.} & Kategori asupaniodium & & & & & \\
\hline & Kurang & $1(5 \%)$ & $7(17,5 \%)$ & 0,001 & - & - \\
\hline & Optimal & $16(80 \%)$ & $11(27,5 \%)$ & & & \\
\hline & Lebih & $3(15 \%)$ & $22(55 \%)$ & & & \\
\hline
\end{tabular}

Hasil penelitian menunjukkan bahwa pada kelompok kasus, anak yang mempunyai pajanan pestisida sebanyak $80 \%$, riwayat pajanan asap rokok $80 \%$, riwayat pajanan obat nyamuk $45 \%$, riwayat penggunaan plastik pembungkus makanan panas dalam plastik $60 \%$, mengkonsumsi makanan goiterogen $75 \%$, mengkonsumsi makanan yang mengandung zat selenium $25 \%$, status gizi kurus 30 $\%$, asupan iodium secara optimal sebanyak $80 \%$ sedangkan pada kelompok kontrol anak yang mempunyai pajanan pestisida sebanyak 42,5\%, riwayat pajanan asap rokok $72,5 \%$, riwayat pajanan obat nyamuk $42,5 \%$, riwayat penggunaan plastik pembungkus makanan panas $52,5 \%$, mengkonsumsi makanan goiterogen $60 \%$, mengkonsumsi makanan yang mengandung zat selenium $40 \%$, status gizi kurus $15 \%$, asupan iodium secara optimal sebanyak $27,5 \%$. Variabel penelitian yang berhubungan dengan kejadian goiter adalah riwayat pajanan pestisida dan 
kategori asupan iodium dengan nilai $\mathrm{p}$ masingmasing 0,$013 ; 0,001$

Pajanan pestisida pada anak yang mengalami goiter berasal dari; $75 \%$ responden ikut terlibat dalam kegiatan pertanian, $80 \%$ responden mempunyai kebiasaan bermain di area pertanian, $45 \%$ responden tidak mempunyai kebiasaan mencuci tangan dan sebanyak $60 \%$ responden terpapar dari pengelolaan pestisida di dalam rumah yang kurang baik. Sumber pajanan pestisida yang berhubungan dengan kejadian goiter adalah keterlibatan anak dalam kegiatan pertanian, kebiasaan bermain di area pertanian dan pengelolaan pestisida dalam rumah dengan nilai $p$ masing-masing 0,$014 ; 0,013 ; 0,031$

Tabel 4. Hasil Analisis Regresi Logistik Fakor Risiko Kejadian Goiter

\begin{tabular}{|c|c|c|c|c|c|c|}
\hline \multirow{2}{*}{ No } & \multirow{2}{*}{ Variabel } & \multirow{2}{*}{ B } & \multirow{2}{*}{$P$} & \multirow{2}{*}{$\operatorname{Exp}(\mathrm{OR})$} & \multicolumn{2}{|c|}{$95 \% \mathrm{CI}$} \\
\hline & & & & & Lower & Upper \\
\hline 1. & $\begin{array}{l}\text { Keterlibatan anak dalam } \\
\text { bidang pertanian }\end{array}$ & 2,296 & 0,006 & 9,935 & 1,915 & 51,550 \\
\hline 2. & Asupan iodium & $-3,150$ & 0,001 & 0,043 & 0,007 & 0,269 \\
\hline
\end{tabular}

Constanta: $-1,464$

Hasil analisis multivariatpada tabel 4, dimasukkan dalam rumus persamaan regresi logistik maka diperoleh bahwa keterlibatan anak dalam bidang pertanian memiliki probabilitas terkena goiter sebesar $69,6 \%$

\section{Riwayat pajanan pestisida dengan goiter}

Dampak buruk pestisida bukan hanya mengenai petani atau pekerja yang menyemprot pestisida saja, tetapi juga dapat mengenai keluarga dan tetangga di mana kegiatan itu dilakukan. Keracunan pestisida dapat bersifat akut maupun kronis. Keracunan pestisida yang akut ada yang bersifat lokal ada juga yang bersifat sistemik. Keracunan pestisida yang bersifat sistemik dapat menyerang sistem syaraf, hati atau liver, perut, sistem kekebalan dan keseimbangan hormonal.

Pajanan pestisida pada anak-anak ditunjukkan berdasarkan derajat pajanan yang diukur melalui beberapa indikator antara lain; keterlibatan anak pada kegiatan pertanian, riwayat kebiasaan bermain di area pertanian, kebiasaan mencuci tangan, dan pengelolaan pestisida di dalam rumah. Hasil penelitian menunjukkan bahwa pajanan pestisida pada anak yang mengalami goiter berasal dari; $75 \%$ responden ikut terlibat dalam kegiatan pertanian, 80 $\%$ responden mempunyai kebiasaan bermain di area pertanian dan sebanyak $60 \%$ responden terpapar dari pengelolaan pestisida di dalam rumah yang kurang baik. Pajanan pestisida dapat terjadimelalui kulit, sistem pernafasan, maupun sistem pencernaan anaktersebut. Hasil uji statistik menunjukkan bahwa ada hubungan yang bermakna antara riwayat pajanan pestisida dengan dengankejadian goiternilai $p$-value: 0,013 ( $<<0,05) ;$ Odds Ratio (OR):5,41 artinya responden yang mempunyai riwayat pajanan pestisida mempunyai peluang $5,41 \mathrm{kali}$ untuk terjadi goiter dibandingkan dengan responden yang tidak mempunyai riwayat pajanan.

Pajanan pestisida terakumulasi dalam tubuh dan dapat diketahui melalui aktifitas enzim kolinestrase tubuh. Penelitian yang dilakukan oleh Aji tahun 2013 menyimpulkan bahwa ada hubungan yang signifikan antara kadar TSH dengan kadar enzim Kolinesterase dalam darah pada wanita usia subur di daerah pertanian hortikultura desa Gombong Kecamatan Belik Pemalang $(p$ value $=0,0001)$, dengan koefisien korelasi $-0,600$ membentuk tren negatif yang artinya semakin tinggi kadar TSH semakin rendah kadar kolinesterase responden dengan kategori kekuatan hubungan kuat. ${ }^{11}$

Mekanisme gangguan pada kelenjar tiroid (kejadian goiter) akibat pajanan pestisida antara lain: dapat melalui hambatan terhadap proses pengikatan hormon tiroid (HT) oleh reseptor tiroid (TR) di dalam sel, hambatan terhadap proses deiodinasi di tingkat perifer, hambatan terhadap proses deiodinasi di tingkat hati. Ketiga hambatan tersebut akan berdampak pada kurangnya kadar hormon tiroid. Kejadian ini akan merangsang kelenjar hipotisis untuk memproduksi hormon Thyroid Stimulating Hormone (TSH) yang akan memacu kelenjar tiroid untuk memproduksi HT. Hal ini akan menyebabkan terjadinya hipertrofi kelenjar tiroid (goiter). ${ }^{6}$

Pajanan pestisida pada anak-anak berasal dari berbagai macam aktifitas yang berkaitan dengan kegiatan pertanian baik secara langsung maupun tidak langsung. Paparan pestisida secara langsung dapat terjadi melalui kebiasaan membantu orang tua dalam kegiatan pertanian dan kebiasaan mencuci tangan. Pajanan secara tidak langsung.dapat melalui kebiasaan bermain di area pertanian yang dimungkinkan mengandung residupestisida yang tertinggal dalam tanah maupun tanaman yang berada di lahan pertanian dan pengelolaan pestisida di dalam rumah yang kurang baik seperti membuang bekas wadah pestisida sembarangan sehingga berpotensi digunakan uantuk alat bermain anak-anak. Hasil penelitian menunjukkan bahwa $75 \%$ responden pada kelompok kasus goiter terlibat dalam kegiatan pertanian lebih besar di banding responden kelompok kontrol yaitu sebesar $37,5 \%$.

Hasil penelitian yang dilakukan oleh Puspitasari tahun 2014 menunjukkan adanya hubungan antara keterlibatan anak dalam kegiatan pertanian dengan kejadian goiterpada anak sekolah dasar di Kecamatan Pakis Kabupaten Magelang. Paparan pestisida terhadap kejadian goiter sangat berpengaruh karena 
keberadaan pestisida dalam tubuh dapat mengganggu kerja fungsi tiroid. ${ }^{12}$

\section{Riwayat pajananasap rokok dengan goiter}

Paparan asap rokok pada penelitian ini tidak berhubungan dengan kejadian goiter, karena pada responden yang terkena goiter maupun tidak mengalami goiter sebagian besar $(80 \%)$ mempunyai riwayat paparan asap rokok. Pajananasap rokok disebabkan dari anggota keluarga yang merokok di dalam rumah $(75 \%)$ dan melakukan aktifitas berdekatan dengan responden (85\%). Asap rokok mengandung ribuan zat kimia, Komponen asap yang paling luas dikenal adalah tar, nikotin, dan karbon monoksida (CO). Sebagian besar zat kimia dalam asap rokok bukan merupakan zat yang mempengaruhi kelenjar tiroid. Selain nikotin dan karbon monoksida, otoritas kesehatan masyarakat telah menggolongkan sekitar 70 di antaranya sebagai kemungkinan penyebab penyakit terkait merokok. Sebagian dari komponen ini adalah arsenik, benzena, benzo pirena, logam berat (timbal, kadmium), hidrogen sianida, dan nitrosamina khusus tembakau. ${ }^{13}$

\section{Riwayat pajanan obat nyamuk dengan goiter}

Obat anti nyamuk merupakan pestisida yang paling sering digunakan dalam rumah tangga. Terdapat jenis sediaan anti nyamuk, yaitu bakar, semprot, elektrik dan oles. Hasil penelitian menunjukkan bahwa tidak ada hubungan yang bermakna antara riwayat pajanan obat nyamuk dengan kejadian goiter, nilai $p$-value: 1,000 ( $\mathrm{p}>0,05)$. Paparan pestisida pada obat nyamuk belum secara signifikan menimbulkan dampak terhadap tubuh subyek dan menimbulkan dampak kesehatan, hal tersebut dapat dipengaruhi oleh lama paparan dan dosis pemakaian obat nyamuk. Sebagian besar $(60 \%)$ subyek penelitian tidak memiliki riwayat pemakain obat nyamuk, karena pada wilayah dataran tinggi dengan suhu dingin perkembangbiakan nyamuk tidak maksimal dan jarang ditemukan nyamuk.

Penelitian oleh Amelia tahun 2015 tentang Hubungan Lama Penggunaan Obat Anti Nyamuk Bakar dengan Kadar Kolinesterase Darah pada Masyarakat Kelurahan Jati Rumah Gadang Padang menyimpulkan bahwa berarti tidak terdapat hubungan yang bermakna antara lama penggunaan obat anti nyamuk bakar dengan penurunan kadar kolinesterase darah dengan nilai $\mathrm{p}=0,395 .{ }^{14}$

\section{Riwayat penggunaan plastik pembungkus makanan panas dengan goiter}

Penelitian ini menunjukkan bahwatidak ada hubungan yang bermakna antara riwayat paparan senyawa kimia dalam plastik dengan kejadian goiter nilai p-value: $0,783 \quad(\mathrm{p}>0,05)$. Hal tersebut dikarenakan pada responden yang terkena goiter maupun tidak mengalami goiter sebagian besar mempunyai paparan senyawa kimia plastik dari pembungkus makanan jajanan. Paparan senyawa kimia plastik yang berasal dari plastik pembungkus makanan jajanan, tidak mempunyai senyawa kimia Bisfenol A yang dapat menekan fungsi tiroid melalui gangguan pada proses transkripsi reseptor tiroid (TR) sehingga mekanisme ikatan tiroid dengan reseptor tersebut terganggu.Plastik yang digunakan untuk pembungkus makanan jajanan merupakan plastik yang berbahan dasar monomer yaitu vinil klorida, akrilonitril, metacrylonitil, vinylidene klorida serta styrene. Pemakaian tempat plastik untuk membungkus makanan menyebabkan monomermonomer plastik ikut bercampur dengan makanan. Migrasi monomer terjadi karena dipengaruhi oleh suhu makanan atau penyimpanan dan proses pengolahannya. $^{13}$

Penelitian yang dilakukan oleh M. Sulchan tahun 2007 mengenai keamanan pangan kemasan plastik dan Styrofoam menyimpulkan bahwa sifat berbagai bahan Penggunaan kemasan plastik untuk makanan/minuman dengan temperatur tinggi akan menyebabkan migrasi monomer-monomer bahan dasar plastic bercampur dengan bahan makanan, sehingga secara tidak langsung mengkonsumsi zat-zat yang bermigrasi tersebut. Vinil Khlorida dan akrilonitril merupakan monomer-monomer yang berbahaya karena cukup tinggi potensinya untuk menimbulkan kanker. ${ }^{15}$

\section{Status gizi dengan goiter}

Indikator IMT/U merupakan indikator yang paling baik untuk mengukur keadaan status gizi yang menggambarkan keadaan status gizi masa lalu dan masa kini karena berat badan memiliki hubungan linier dengan tinggi badan. Pada keadaan normal, perkembangan berat badan akan searah dengan pertumbuhan tinggi badan dengan kecepatan tertentu. Hasil penelitian menunjukkan bahwa tidak ada hubungan yang bermakna antara status gizi anak dengan kejadian goiter (p: 0,304>0,05) Tidak adanya hubungan status gizi dengan kejadian goiter di wilayah penelitian, hal ini disebabkan jumlah respoden dengan status gizi kurang pada kelompok kasus sebesar $30 \%$ dan tidak ada sampel yang menderita gizi buruk. Gangguan penyerapan yodium hanya akan berpengaruh pada kondisi kekurangan gizi berat yang kronis. Status gizi seseorang merupakan salah satu faktor yang dapat mempengaruhi jumlah cadangan yodium dalam tubuh karena lemak adalah tempat penyimpanan sebagian besar cadangan yodium di dalam tubuh.

Cadangan lemak merupakan tempat penyimpanan iodium. Jumlah simpanan iodium di dalam tubuh setiap individu akan berbeda sesuai dengan kondisi status gizinya. Kadar iodium urine anak dengan status gizi baik lebih tinggi dibandingkan dengan anak dengan status gizi kurang setelah diberikan kapsul iodium selama 3 hari berturut-turut. Status gizi kurang atau buruk akan berisiko pada biosintesis hormon tiroid karena kurangnya TBP (Thyroxin binding Protein), sehingga sintesis hormon tiroid akan berkurang.

\section{Asupaniodium dengan goiter}

Kecukupan yodium tubuh dinilai dari yodium yang masuk lewat makanan dan minuman, sebab 
tubuh manusia tidak dapat mensintesis yodium. Yodium dengan mudah diabsorpsi dalam bentuk iodida. Ekskresi dilakukan melalui ginjal dan jumlahnya berkaitan dengan konsumsi yodium, dengan demikian UIE jelas dapat menggambarkan intake yodium seseorang. Kadar UIE dianggap sebagai tanda biokimia yang dapat digunakan untuk mengetahui adanya defisiensi yodium dalam suatu wilayah.

Hasil Pemeriksaan sampel urine responden untuk mengetahui kadar EIU yang dapat menggambarkan asupanyodium seseorang. Pemeriksaan dilakukan di laboratorium GAKI UNDIP Semarang. Hasil analisis pemeriksaan kadar EIU menunjukkan bahwa kadar Ekskresi Iodium Urin (EIU) pada anak SD di Kecamatan Ngablakmempunyai nilai rata rata (Mean) 176,183 $\mu \mathrm{g} / \mathrm{L}$ dengan kisaran $30 \mu \mathrm{g} / \mathrm{L}-291 \mu \mathrm{g} / \mathrm{L}$, nilai median $182 \mu \mathrm{g} /$ Ldengan Standar deviasi 67,068. sebagian besar responden mempunyai kategori intake iodium secara optimal yaitu sebesar $45 \%$. Hasil uji statistik dengan uji statistik diperoleh nilai $p$-value: $0,001(\mathrm{p}<0,05)$. Berarti ada hubungan yang bermakna antara intake iodium dengan kejadian goiter. Penelitian ini sejalan dengan penelitian yang dilakukan oleh Hafnibahtiar tahun 2009 yang menyatakan bahwa ada perbedaan kadar EIU antara kelompok subyek gondok dengan tidak gondok. nilai $\mathrm{P}=0,025{ }^{16}$

Iodium adalah bahan baku pembuatan hormon Tiroksin (T4), sedangkan tempat pembuatannya adalah di dalam kelenjar tiroid. Produksi Triiodotironine(T3) tergantung dari hormon tiroksin (T4). Pada kondisi defisiensi iodium, Hypothalamus akan merangsang produksi TSH (Thyroid Stimulating Hormon) untuk menstimulasi kelenjar tiroid memproduksi hormon T1, T2, T3, T4. Tiroid beradaptasi pada saat defisiensi iodium tergantung fleksibilitas kelenjar tiroid pada setiap tahap metabolisme iodium dan pada kemampuan untuk meningkatkan efisiensi melalui stimulasi TSH. Besar variasi respon antar individu diukur dengan prevalensi gondok dan konsekuensi-konsekuensi lainnya. ${ }^{17}$

Apabila asupan iodium kurang maka kelenjar tiroid tidak mampu mempertahankan sekresi hormon yang adekuat, sebaliknya asupan yang berlebihan dapat menimbulkan iodium toksin. Asupan iodium pada kadar yang tinggi dalam jangka waktu lama dapat menimbulkan gejala hipertiroid dan tirotoksikosis. kelebihan iodium dapat meningkatkan kejadian autoimun tiroid, kanker tiroid, dan iodine induce hyperthyroidism. ${ }^{17}$

Kebutuhan yodium dapat diperoleh melalui makanan dan minuman, kandungan yodium dalam makanan mempunyai variasi yang sangat luas, dan sangat tergantung dari kandungan yodium dalam tanah tempat mereka tumbuh. Selain itu kebutuhan iodium dapat diperoleh dari pemakaian garam beryodium dan pemberian kapsul beriodium pada anak-anak. ${ }^{5}$ Pada penelitian ini menunjukkan bahwa proporsi subyek pada kelompok kasus yang mengkonsumsi garam beryodium sebesar $25 \%$ lebih kecil di banding responden kelompok kontrol yaitu sebesar $62,5 \%$.

Penelitian yang dilakukan oleh Samsudin tahun 2015 tentang pengaruh penggunaan garam beriodium standar terhadap status iodium anak sekolah dasar yang mengonsumsi makanan sumber iodium tinggi di daerah non endemic menyimpulkan bahwa Intervensi "garam beriodium standar" ( $>=30$ ppm KIO3) di wilayah pantai (konsumsi makanan sumber iodium tinggi), masih memberikan nilai median EIU normal pada anak ${ }^{18}$

\section{SIMPULAN}

Variabel yang berhubungan dengan kejadian goiter pada anak usia sekolah dasar di area pertanian hortikultura Kecamatan Ngablak Kabupaten Magelang adalah riwayat pajanan pestisida $\mathrm{p}=0,013$ $(<0,05)$; (OR):5,41 $95 \%$ CI; 1,532-19,123 dan asupan iodium $(p$-value $=0,001)$. Riwayat pajanan pestisida pada anak-anak dipeeroleh dari antara lain; keterlibatan anak-anak dalam kegiatan pertanian, kebiasaan anak bermain di area pertanian serta pengelolaan pestisida di dalam rumah. Variabel keterlibatan anak pada kegiatan pertanian merupakan faktor yang paling berpengaruh terhadap kejadian goiter dengan probabilitas sebesar 69,6\%.

\section{DAFTAR PUSTAKA}

1. Susanto R. Kelainan tiroid pada masa bayi. Bagian Ilmu Kesehatan Anak FK Undip/ RS dr. Kariadi, Tyroidology Update, Semarang; 2009.

2. Djokomoeljanto R. Gangguan akibat kekurangan iodium (GAKI) dan kelebihan iodium EKSES). tiroidologiklinik. Semarang: Badan Penerbit Universitas Diponegoro; 2007

3. Roman GC. Autism: Transient in utero hypothyroxinemia related to maternal flavonoid ingestion during pregnancy and to other environmental antithyroid agents. J Neurol Sci, 2007: 262(2):15-26.

4. World Health Organization. Assessment of iodine deficiency disorders and monitoring their elimination. a guide for programme managers. third edition. Genewa: WHO; 2007

5. Kartono D, Moeljanto D. Total goiter rate (tgr), ekskresi iodium urine (eiu) dan konsumsi garam beriodium Di Propinsi Jawa Tengah. Bul.Penel.Kesehatan; 2008, 36(2): 91-98

6. Koibuchi N. Mechanism of chemical desruptors of thyroid function. Japan: Department of Integrative PhysiologyGunma University Graduate School of Medicine; 2010

7. Rasipin, Suhartono, Kartini A, Aeny N. Faktorfaktor yang berhubungan dengan kejadian goiter (gondok) pada siswa sd di wilayah pertanian. 
Prosiding Seminar Ilmiah Nasional GAKI; 2012, 146-155

8. Sungkawa,H.B, Setiani. O, Suhartono, Hubungan paparan pestisida dengan kejadian goiter pada petani hortikultura di kecamatan Ngablak kabupaten Magelang, J Kesehatan Lingkungan Indones. Oktober. 2007, 6(02): 4146

9. Kristinatalia D. Hubungan kandungan arsen (as) dalam urin dengan kejadian goiter pada petani sayur yang terpapar pestisida di Kecamatan Ngablak Kabupaten Magelang. Jurnal Kesehatan Masyarakat; 2013, 02(1): 332-340

10. Suhartono. Laporan Penelitian Paparan Pestisida dan Fungsi Tiroid pada Siswa SD Kabupaten Brebes. 2013.

11. Aji D, Suhartono, Suwondo A, Hubungan pajanan pestisida dengan kejadian hipotiroid pada wanita usia subur di daerah pertanian hortikultura Desa Gombong Kecamatan Belik Pemalang Jurnal Kesehatan Lingkungan Indonesia, Oktober, 2013, 12(2): 138-143

12. Puspitasari, A. Hubungan antara riwayat pajanan pestisida dengan kejadian goiter pada anak sekolah dasar di Kecamatan Pakis Kabupaten Magelang.2014,

http://eprints.undip.ac.id/44671/1/4962.pdf

13. Gondodiputro S.Bahaya tembakau dan bentukbentuk sediaan tembakau. Bandung. Fakultas Kedokteran Universitas Padjadjaran. 2007

14. Amelia,Yustini Alioes, Sofina Rus. Hubungan lama penggunaan obat anti nyamuk bakar dengan kadar kolinesterasedarah pada masyarakat Kelurahan Jati Rumah Gadang Padang. Jurnal Kesehatan Andalas. 2015, 4(2): 577-581

15. Mohammad Sulchan, Endang Nur W, Keamanan Pangan Kemasan Plastik dan Styrofoam Maj Kedokt Indon, Pebruari, 2007, 57(2): 54-59

16. Bachtiar H, Faktor determinan kejadian gondok di daerah pantai Jawa Timur Jurnal Kesehatan Masyarakat, Maret - September, 2009, 03(2): 62-67

17. David SE, Gangguan Kelenjar Tiroid, dalam Price A. Sylvia, Lorraine M, Wilson. Patofisiologi: Konsep Klinis Proses-Proses Penyakit. Jakarta: EGC; 2006.

18. Samsudin M, Kusumawardani HD, Prihatmi EB, Pengaruh penggunaan garam beriodium standar terhadap status iodium anak sekolah dasar yang mengonsumsi makanan sumber iodium tinggi di daerah non endemik GMI, Desember, 2015, 7(1) : 57-68 